\title{
Diskurzivní analýza Národních listů: národ vs. islám a Laclauův populistický matrix ${ }^{1}$
}

\author{
A Discursive Analysis of Národní listy: Nation vs. Islam and the Laclau Matrix
}

\author{
ONDŘEJ STULÍK ${ }^{2}$
}

\begin{abstract}
This article deals with the phenomenon of populism and the form it takes in the context of the Úsvit - národni koalice party and the Blok proti islamu coalition. The methodology of the analysis is based on Laclau's account of populism and includes a discursive analysis of the populist mentality as a tool to form a vague argument against "bad" Islam culture. These assumptions are tested by a summative content analysis and are contextualized by a metaphor analysis. The results confirm all assumptions: Úsvit and Blok create a specific populist mentality based on a negative perception of Islam, a positive (but empty) national identity, and a simplified critique of the current establishment framed as tool for spreading bad culture which is based on the ideology of Muslims and Islam.
\end{abstract}

Keywords: Blok proti islámu; Content Analysis; Islam; National Identity; Populism; Úsvitnárodni koalice

\section{1. Úvodem}

Sdělovací prostředky a aktéři, kteří v nich vystupují, používají různé výrazy pro označení politického či sociálního problému, případně svého postoje k němu, pro přiblížení kontextu řešení, nabídky alternativy apod. Sociální vědy tyto výrazy, jejich způsob užití a kontext, který vytváří, zkoumají, aby odhalily smysl a poprúpadě i důvod jejich užití. Cílem je vysvětlit účel řečeného, označit záměry aktérů, popřípadě zasadit řečené do širšího teoretického rámce a upozornit tak na skrytý kontext či alternativní chápání vybraného zkoumaného pojmu z oblasti

\footnotetext{
1 Zpracování textu bylo podpořeno z projektu SGS 2016-030, který poskytla Západočeská univerzita v Plzni pro rok 2016.

2 Odborný asistent, Katedra politologie a mezinárodních vztahů, Fakulta filozofická, Západočeská univerzita v Plzni; Jungmannova 1, Plzeň / Department of Politics and International Relations, Faculty of Philosophy and Arts, University of West Bohemia, Plzeň, Czech Republic. Contact: stulik@kap.zcu.cz.
} 
sociálních věd, který je však užit v praxi konkrétními politickými aktéry. Výčet cílů sociálních věd a specificky politologie by byl rozsáhlý, nicméně reakce na aktuální politické dění rámované aktéry používajícími pojmy z politického, a tak i politologického prostředí, je důležitou součástí vysvětlovací funkce politické vědy.

Mezi frekventované výrazy, které můžeme $\mathrm{v}$ současnosti $\mathrm{v}$ médiích zaznamenat, patří „islám“ a „národ“, a to (nejen) v souvislosti s tzv. migrační krizí. Užívání zmíněných výrazů je analyticky problematické, protože kontext, ve kterém jsou použíány, nelze vždy přesně určit a nelze ani jednoznačně vysvětlit, v jakém smyslu jsou tyto výrazy používány a co by měly označovat. Důvodem je množství aktérů a kontextů $\mathrm{v}$ politickém prostoru, které každým okamžikem stoupá. Dalším důvodem je nemožnost vždy od daných aktérů získat informace či obsáhnout všechny aktéry, byt' by působili v rámci jednoho úžeji vymezeného diskurzivního společenství. I přes takové komplikace je možné předpokládat, že někteří vybraní aktéři (politické strany, politická hnutí, zájmové skupiny apod.), jejichž relevanci vůči zkoumaným výrazům je třeba určit skrze transparentní kritéria př́padové studie, užívají tyto výrazy konzistentním způsobem, a to bud' pejorativně, nebo veskrze pozitivně. Určením takového hodnotově zabarveného významu problém nekončí. Vysvětlit, co nějaké politické straně nebo jinému aktérovi nap̌r. na islámu vadí nebo nevadí (a proč), nestačí; analýza tohoto typu postrádá smysl. Ten je nutné určit vưči širšímu teoretickému problému politické vědy. Problém, který se u politických aktérů užívajících výrazy islám a národ objevuje, je jejich označování termínem populisté. Podobně způsoby, jakými jsou termíny islám a národ používány co do formy, jsou chápány jako populistické.

Účelem analýzy této studie je stanovení kontextu, v němž se reprodukuje rozumění termínu „národ“ u řečového společenství politických aktérů, kteří se hlásili se ke koalici politické strany Úsvit - národni koalice a zájmové skupiny Blok proti islámu, stejně jako jeho předpokládaného významového opozitu, který je možné kontextuálně vyjádřit termínem ,islám“. Stanovení kontextu rozumění může dle laclauovské perspektivy přispět k pochopení mechanismu vytváření populistické mentality prostřednictvím formulace opozitu a tím spoluutvářet vlastní diskurzivní představu o českém národě jako součásti vlastního politického programu. Z tohoto důvodu bude analyzováno periodikum Národní listy, protože se jedná o oficiální stranický tisk koalice zmíněných aktérů vyjadřující ambici vykládat jejich vlastní programové priority. Oficiální charakter periodika je důležitý, protože se tak oslabuje možnost bagatelizace jeho obsahové hodnoty a kontextu, jež jsou pak rámovány jako „osobní názor“ - jak se stalo u kontroverzních „facebookových výrokư“ Martina Konvičky, jednoho $z$ dřivějších představitelů Bloku proti islámu. Dalším důvodem je možnost zlehčování výroků jako „vytržených z kontextu“ (viz např́iklad ČRo 2016), která je u ucelených článků na jedno téma u stranického tisku oslabena a tím je umožněno 
zkoumání širšího kontextu (podobně jako v př́ípadě analýzy politického programu).

Konkrétním cílem této studie je odhalit, v rámci daného časového období, diskurzivní praktiky v podání vedení politické strany Úsvit - národní koalice a zájmové skupiny Blok proti islámu, jež se týkaly tvorby české národní identity jakožto nástroje pro odůvodnění existence vlastní politické linie a posílení mentality „českosti“ jako populistické alternativy vůči - z pohledu obou uskupení - neprrijatelnému politickému mainstreamu. Širším záměrem textu je přispět $\mathrm{k}$ diskuzi o výzkumu konstitutivních idejí provázejících vznik nových single issue politických stran, poprrípadě rozšiřování programových bodů stávajících politických stran o témata národní a protiislámská. Sledovaným výsekem diskurzivních praktik jsou deklarované představy o ,islámské imigraci“ a ochraně tradičních (tj. evropských či českých) hodnot, přičemž náplň těchto představ má podpořit utváření populistické mentality. Předpokladem úspěchu této snahy je pak hodnotově zatížená stereotypizace výrazů „národ“ a „islám“, která může vést k etablování populistické mentality a vyloučení definované skupiny osob, které ideově nespadají pod stereotyp „národ“ (prostřednictvím prrisouzení negativní nálepky „islám“), z veřejného prostoru. Ruku v ruce s takovou hrozbou jde omezení demokratická diskuze, at' už kvůli praktickým projevům stereotypů, nebo např́klad v podobě porušení principu osobního nenapadání v dialogu a deliberaci. ${ }^{3}$

Tvorbu a reprodukci praktických projevů stereotypů je možné zachytit prostřednictvím laclauovské diskurzivní perspektivy, která spojuje téma populismu a demokracie (viz sekce 3). Výrazy národ a islám jsou navázány na populismus pravicového single issue typu prostřednictvím konstrukce (národni) identity v opozitu $\mathrm{k}$ identitě cizí (islám). Národ a islám tak tvoří objekty výzkumu, zatímco populismus je jako pojem nutnou podmínkou dané politologické teorie, která má vysvětlovací funkci. ${ }^{4}$

3 V tomto př́padě se jedná přímo o podmínky vedení dialogu pro tvorbu veřejnosti a deliberovaného veřejného mínění. $K$ tomu viz např. Habermas (2000).

${ }^{4}$ Určení všech tři termínů může být proměnlivé, protože jsou bud' chápány jako výrazy sociální vědou zkoumané, nebo jako pojmy sociální vědy, skrze něž lze sociální realitu analyzovat. V prvním př́ipadě je výzkum veden snahou odhalit konkrétní kontexty užívání výrazů v konkrétních situacích, místním určení a čase. To znamená, že nejde o pokus o definici těchto termínů, ale o označení diskurzivních praktik. Jednodušeji řečeno: Jde o formulaci toho, jak o daném tématu daný okruh osob mluví a co si o něm tedy v nějakém časovém horizontu myslí. $\mathrm{V}$ druhém př́padě se aplikuje teorie např. pro typologizaci a podrobnou charakterizaci zkoumaných výrazů. Výzkum směřuje $\mathrm{k}$ vysvětlení diskurzivních praktik, konstrukci typologie a vyvození obecně platných závěrů. Problém volby př́istupu k chápání role termínů je spjat s rozdíly mezi politickým věděním a politickým míněním (viz nap̌r. Strauss 1995; Voegelin 2000 a dalšîi). 


\section{Populismus v Evropě a ČR - postavení Úsvitu a Bloku}

Pro odlišení typů stranických organizací měl zásadní význam Maurice Duverger Téma populismu vEvropě je v současnosti spjaté především se vznikem nových politických stran typu single issue a s obecnější diskuzí o demokracii a jejích hranicích, v souvislosti s reakcí politických elit na ekonomickou krizi a tzv. uprchlickou krizi. ${ }^{5}$ Dopady ekonomické krize na společnost, které se projevovaly nejistotou občanů a ze strany některých politických aktérů pocitem nutnosti rétoricky chránit a obhajovat ekonomicky postižené vrstvy společnosti, se přelily do kritiky stávajících politických elit jako viníků odpovědných za daný stav. Tím došlo k částečné erozi stranických systémů a vytvořil se prostor pro vznik nových subjektů, politicky se opírajících o rétoriku oddělující to „staré a klasické, co nefunguje“ od toho „nového“, volajícího - s vidinou mobilizace doposud pasivních voličů - po odpovědnosti „špatných“ politiků krizové éry. Zvýšený potenciál nových politických subjektů, které bývají označovány jako populistické, můžeme zaznamenat ve stranických systémech, které nejsou stabilizované a mají relativně krátký demokratický vývoj. Podle Kriesiho a Pappase (2015: 3) se takový zvýšený potenciál týká především stranických systémů střední a východní Evropy. V českém prostředí již byl fenomén populismu $\mathrm{v}$ nastíněných intencích zkoumán, nicméně př́padových studií není mnoho a absentuje naprýklad studie politické strany Úsvit - národní koalice, jež by byla opřená o výzkum zaměřený na diskurzivní praktiky, které toto uskupení svou politikou vytváŕí, stejně jako obsah politického programu či oficiálního stranického periodika.

Uprchlická krize je druhým stimulem, který se podepisuje na zvýšené frekvenci kritiky stávajících elit a tvorby politiky elit alternativních s cílem reprezentovat podle nich strádající občany. V této souvislosti má frustrace formu ruptury identity, nikoliv ekonomického statusu, byt' jsou oba fenomény do jisté míry provázány. $Z$ tohoto důvodu je snaha alespoň rétoriku vztahující se $\mathrm{k}$ identitě posilovat - např́klad vytvářením stereotypů o vlastním národě nebo naopak o cizích (vnějších) kulturních prvcích.

Volební potenciál některých pravicových populistických stran v Evropě dosahuje hodnoty okolo deseti procent (viz např. Stockemer 2016). Některé zavedené strany na druhou stranu přebírají rétoriku stran populistických (imigraci vnímají negativně a prosazují konzervativní hodnoty; viz např. Odmalm a Bale 2015). ${ }^{6}$ Oba faktory jsou důležité pro pochopení trendů v rétorice populistických

\footnotetext{
${ }^{5} \mathrm{Na}$ druhou stranu je třeba poznamenat, že tento typ výzkumů není zcela nový a single issue strany pravicového populistického ražení nejsou fenoménem, který by se objevil až po ekonomické či uprchlické krizi (viz napr. Dunn 2015).

${ }^{6} \mathrm{Z}$ perspektivy vývoje veřejného mínění se jim věnuje např́klad Timothy Hatton ve své rozsáhlé studii Immigration, public opinion and the recession in Europe (2016) nebo napríklad Cas Mudde a
} 
stran a oba jsou v př́padě stranické politiky České republiky př́tomné (jsou navázány na širší protestní potenciál a charisma představitelů daných stran, což je trend dlouhodobější; viz např. Císař a Štětka 2016). V př́padě Úsvitu - národní koalice šlo především o dưraz na přímou demokracii a odvolatelnost politiků odpovědných za „stav země“, po spojení s Blokem proti islámu a odchodu Tomia Okamury se pak stala jedním z hlavních témat imigrace a s ní spojený pŕíliv islámu, který má Českou republiku nejen vyčerpávat ekonomicky, ale především naleptává její kulturu. Tento článek se zaměřuje na druhé jmenované téma, tedy na rétorickou konstrukci české identity proti islámu jako důsledek imigrační a ekonomické krize spjaté s nárůstem pravicového populismu. Výzkum těchto témat není ve středoevropském prostoru zcela zanedbáván, ovšem výchozí teze pro formování populistických představ nejsou lingvisticky (a s politologickou perspektivou) zmapovány.

To souvisí i s výzkumnými předpoklady této studie, přičemž ověření druhého z nich je jejím hlavním cílem: Za prvé, politická strana Úsvit - národní koalice (dále také jen „Úsvit") je relevantní. Za druhé, Úsvit v kooperaci se spolkem Blok proti islámu (dále také jen „Blok“) užívají výraz „islám/islam-“ pejorativně a výraz „národ“ pozitivně z toho důvodu, že se snaží vytvořit pejorativní obsah referenčního pojmu ,islám“, vůči kterému by mohly pozitivně dotvářet obsah termínu „národ“ a tím vytvářet vlastní diskurzivní představu o výrazu „národ“. Výraz národ má následně, skrze svůj rétoricky vytvořený obsah, sloužit jako apel na voliče, čímž politická strana a spolek plní jeden ze svých základních cílů, tj. získávání lidové podpory (Novák 1997: 23-24). Obsah výrazu národ je přitom spoluvytvářen obsahem pojmu islám, a to $\mathrm{v}$ opozici vůči fenoménu současné imigrační vlny do Evropy. Ověření předpokladu o Úsvitu jako relevantní a důležité politické straně (viz např. Sartori 2005: 126-128) by si zasloužilo vlastní analýzu, na kterou zde není prostor. Přesto je možné upozornit na přinejmenším dva faktory, které by mohly předpoklad o relevanci Úsvitu a Bloku potvrzovat. Prvním faktorem je volební potenciál, který se dle agentury Median pohyboval mezi lednem a květnem roku $2016 \mathrm{v}$ rozsahu 2,5-3,5 procent podpory (Median 2016a, 2016b, 2016c, 2016d, 2016e), kterýžto výsledek by tomuto uskupení umožnil dosáhnout na státní prŕspěvek pro svou činnost a kontinuálně svơj volební potenciál zvyšovat až do míry koaličního či vyděračského potenciálu. Druhým faktorem je zastoupení této strany v poslanecké sněmovně v celkovém počtu sedmi poslanců (PSPČR 2016).

\section{Laclaư̊v populistický matrix a sumativní obsahová analýza}

Termín populismus provází různé snahy o analytické uchopení, a to vždy vzhledem $\mathrm{k}$ účelu a vytyčenému předmětu výzkumu. Zmapovat celý vývoj termínu

Cristóbal Rovira Kaltwasser v pracovním textu Voices of the peoples: Populism in Europe and Latin America Compared (2011). 
nebo jeho současných variací pro analytické užití není možné, a i kdyby možné bylo, postrádalo by smysl. Populismus je tak podobně jako jiné pojmy ze sociálních věd komplikovaně definovatelný ${ }^{7}$ a uchopitelný je vždy pouze vhledem ke zvolené perspektivě. Jedním z největších problémů, který je v souvislosti s populismem zmiňován, je nejasnost, zda je ideologií nebo patř́ k obecněji pojatým sociálním hnutím (Laclau 1977: 144; Laclau 2005: 73). ${ }^{8}$ I kdyby bylo možné rozhodnout, zda je populismus ideologií, hnutím, poprípadě něčím jiným, vyvstanou otázky jiné, které se týkají vztahu populismu a demokracie, populismu a zkoumání diskurzu, populismu a stylu politiky, popř́padě rétoriky, technik a podobně. Povahu populismu zkrátka není možné jednoznačně vymezit a svázat ji s nějakým jiným konkrétním tématem (Fieschi 2004: 235). V této studii má ale prioritu vztah obsahu populismu k demokracii a analyticky vzato pak vztah populismu a diskurzivních praktik.

I přes nemožnost minimální definice populismu je možné vyzdvihnout variaci prvků, které jsou pod tento termín řazeny. Prvním je skutečnost, že populisté, jako protagonisté emitující populismus, jsou politiky, kteří se vymezují proti politice jako takové a stylizují se do role „obyčejných lidí“, případně jedinců, kteří na straně „obyčejných lidí“ stojí (Pratt 2007: 10). Jak vymezit politika a tzv. obyčejné lidi je sice $\mathrm{z}$ analytického hlediska problematické, nicméně lze konstatovat, že populisté mají tendenci (což je další prvek charakterizují populismus jako takový) realitu simplifikovat na dva možné výklady: Představu toho, který hájí zájmy nás, obyčejných lidí, a toho, který hájí zájmy jich - tedy politiků, kteří jsou u moci a svou moc proti „nám“ uplatňují (viz nap̌r. Hayward 2004: 10; Acemoglu et al. 2013: 771). Třetím prvkem, který navazuje na dva předešlé, je snaha populistů vybudovat specifickou mentalitu (popř́padě ideologii), podle které by se tzv. obyčejní lidé ŕídili (srov. Pasquino 2008: 20). Tzv. obyčejní lidé jsou diskurzivním konstruktem, který populista skrze mentalitu vytváríi. Populista tak může měnit černobílou realitu (my versus oni) poměrně flexibilně a populismus díky tomu bývá označován za tzv. chameleonský jev (Fieschi 2004: 236). ${ }^{9}$

\footnotetext{
7 Podle Laclaua (1977: 143; srov. Canovan 1982; Stavrakakis 2004) ale jeden rozdíl mezi populismem jinými termíny sociálních věd je: Snaha o uchopení pojmu populismus je jednou z nejméně precizních. Vágnost populismu vychází z jeho enormního nadužívání v rozdílných kontextech a u rozdílných aktérů (média, politici, sociální vědci, občané apod.).

${ }^{8}$ Dle selektivního určení prvků lze rozlišovat populismus pravicový a levicový jako samostatné kategorie. Pro využití tohoto dělení by bylo ale nutné definovat pravicovost a levicovost, př́ipadně navázat populismus na existující politické ideologie (srov. napr. Wodak 2015). Takový postup je možný (viz např. Betz 1994), ale v tomto článku aplikován není.

${ }^{9}$ Populismus je možné uchopit různými zpo̊soby, a přestože jejich výčet nemůže být nikdy úplný, lze zmínit několik alternativ $\mathrm{k}$ laclauovské perspektivě, kterou zaujímám v této studii. První z možností je vztáhnout populismus k problému rozvoje, nicméně tento př́stup je marginální i v ekonomické vědě (více viz např. Ziai 2004: 1050). Zadruhé je dle Canovan (1982: 544-545) možné uchopit populismus pomocí dvou strategií (s označením „A“ a „B“). Strategie A spočívá ve
} 
V úvodu byl populismus určen jako jev v současnosti svázaný s několika významnými (nikoliv tedy jedinými) tendencemi. První tendencí je vznik nových politických stran $v$ Evropě, které jsou specificky populistické a hlavními tématy jejich politiky je imigrace. Druhou tendencí, která prozatím nebyla zmíněna, ale je ji třeba vzít $\mathrm{v}$ úvahu, je volání populistických politiků po rozsáhlejším zavádění instituce referenda (než bylo doposud doby obvyklé) se současným slibem autentičtější politiky, a to bez ohledu na dopady a efektivitu takové instituce ve vztahu ke stávajícímu politického řádu a jeho nastavení v rámci tradic a podobně. Součástí druhé tendence je vymezování se proti aktuálnímu establishmentu (Pratt 2007: 10-12; Arditi 2007: 43), které je těsně svázáno s demokratickým apelem. Díky druhé tendenci může být populismus označen jako fenomén typický pro demokratické systémy, byt' tomu tak nutně být nemusí. Je třeba ale připomenout výše uvedený poukaz na mentalitu, což je pro Linze (2000: 160-162) hlavní ukazatel autoritářských, tedy nedemokratických režimů. Pokud je populismus $\mathrm{v}$ nějakém demokratickém systému př́tomen, může to být na druhou stranu dle Pasquina (2008: 16) známkou slabosti demokracie. Stejný autor přebírá postoj Ményho a Surela, kteří shrnují tři znaky šíření populismu v demokraciích, jež jdou ruku v ruce stezí o slabosti demokracie. Jedná se o krizi struktury zprostředkování zájmů politické sféry, personalizaci politické moci a posilování pozice médií v politické sfére (Pasquino 2008: 26). Vztah mezi demokracií a populismem není jednoduchý a jednoznačné určení nějakého demokratického typu, který je působení populismu nejnakloněnější (at’ už je populismus chápán jako ideologie nebo jako širší hnutî), není možné.

Populismus je možné uchopit jako analytickou kategorii. Jednou z vhodných konkrétních cest $\mathrm{k}$ uchopení může být „Laclauův populistický matrix“. Tento pojem je inspirován článkem Yannise Stavrakakise (2004), který shrnuje vývoj a upřesňování Laclauova chápání populismu a nabízí tak rámec, na který je možné navázat a aplikovat jej na analýzu Národních listů. Prvním prvkem Laclauova populistického matrixu je chápání populismu jako diskurzu. Druhým prvkem je, že populismus nelze jednoznačně definovat, protože je vždy dán diskurzivními

snaze všechny př́pady domnělého populismu podřadit pod jeden teoretický rámec a určit strukturální podobu takového zastřešujícího populismu (podobně jako fyzici odkrývají strukturu nějaké látky či hmoty). Strategie B spíše připomíná trrídění živočichů do tříd, kmenů apod., protože jde o kategorizaci a typologizaci unikátních fenoménů, mezi nimiž existuje souvislost, ale samy o sobě jsou tak rozdílné, že pokud bychom je nazvali jedním názvem, mělo by to nulovou vypovídající hodnotu. Třetí možností je uchopit populismus personalizovaně a soustředit se na lídry populistických hnutí, jejich vystupování, uplatňování charismatu skrze formy sebeprezentace apod. (tento způsob uchopení populismu je navázán na výzkum médií, mediálních strategií apod.). Personalizovaný populismus vychází z populistického prvku snahy o přiblížení tzv. obyčejným lidem a př́padně jejich (alespoň rétorickou) reprezentaci vůči zavedenému establishmentu. V takovém př́padě je užita rétorika stylu „my jsme dobří a „oni jsou špatní“ v kombinaci s osobním charismatem lídra populistického hnutí. Personalizovaný populismus odděluje ideologii a populismus (Mazzoleni 2008: 49-50). 
praktikami konkrétního diskurzivního společenství. Diskurzivní praktiky lze chápat jako určující komponenty sítě kontextuálních vazeb (vztahů), které díky své konstitutivní roli určují smysl a význam symbolů diskurzu (Laclau 2005: 68). Diskurzivní charakter je i odpovědí na to, zda populismus vnímat jako ideologii nebo jako širší sociální fenomén: Populismus je Laclauem chápán jako jeden z komponentů sociálního hnutí a neměl být redukován na ideologii. ${ }^{10}$ Třetím prvkem je rozdělování společnosti ze strany populistů na základě zjednodušování jinak komplexní sociální reality (Stavrakakis 2004: 254-258), s cílem rozdělit společnost na utlačované bez zastání a utlačovatele, kteří vládnou. Cílem je získat hegemonii v reprezentaci utlačovaných resp. „obyčejných lidí“, kterým populisté („my dobrî́i") vrátí suverenitu v demokratickém rozhodování (Beasley-Murray 2006: 364). Laclauův populistický matrix zužuje postavení populismu jako analytického termínu - jde o jeho formu, nikoliv obsah (tamtéž: 363). Díky takovému chápání role populismu lze diskurzivní charakter zkoumaných dat (z korpusu Národních listů) analyzovat prostřednictvím reprezentativních mocenských praktik utlačovaných (my - národ) a utlačujících (oni - islám). Otázkou však je, zda by bylo možné takové dobytí chápat jako demokratické $v$ prŕpadě, kdy je vytvářením a posilováním stereotypů nadřazována jedna reprezentována skupina (my) a druhá skupina je prostřednictvím labelu naopak marginalizována (islám jako oni).

Populismus tedy není dle Laclaua definován skrze obsah, ale skrze způsob argumentace typický svou asymetričností, která popírá logiku pluralitní diference a staví na sociální frustraci definované skupiny (my - národ) a její odlišnosti od skupiny jiné. Způsob populistické argumentace je řetězový - pokud frustrace vychází z jednoho neuspokojivého stavu, váže se na další a ten na další atd. Tímto způsobem se řetězí problém, až je generalizován na kompletní nevyhovující sociální postavení dotčeného jednotlivce (ze skupiny my). Frustrace je tak posílena a čím je silnější, tím je vyvolávána větší potřeba po řešení oné frustrace a označení (signification) viníka. Je vytvořen vzájemně se vymezující prríčinný řetězec „faktů“ a tímto způsobem se etablují taktéž řetězce stereotypů - jeden označuje frustrovaný stav a druhý jeho príćiny. Smyslem je získat hegemonii ve výkladu politické reality a změnit tak politickou mentalitu. Pokud se na daný stav ale podíváme kriticky, pak prrítomností hegemonie mizí demokratická pluralita (Laclau 2005: 33, 36-43).

Populismus je podle Laclaua unikátním fenoménem a je odlišitelný od ideologie, protože vykazuje podobné charakteristiky jako má autoritářská mentalita, popř́padě hegemonie. Obsahem populismu je důraz na nerovnost „nás“ a ,jich“ (my obyčejní lidé vs. oni politici; popřípadě my obyčejní lidé vs. oni migranti); apel na pravý smysl demokracie (který je viděn v instituci referenda);

10 Laclau reviduje svou vlastní teorii, protože se dříve přikláněl $\mathrm{k}$ chápání populismu jako k ideologie (viz např. Beasley-Murray 2006: 363). 
a důraz na alternativní reprezentaci proti establishmentu. Řetězení různých frustrací a stereotypů může ve výsledku štěpit sociální prostor na dva tábory a tím může být i znemožněna pluralita, $\mathrm{i}$ když by ani jeden $\mathrm{z}$ táborů nedosáhnul hegemonie. ${ }^{11} \mathrm{~V}$ rámci populismu je patrné, že je vystavěn více na formě, než na konkrétním obsahu (i proto je tak těžko uchopitelný). Populismus má jako pojem mlhavé hranice, protože způsob jeho uchopení je určen diskurzivními praktikami a jejich řetězením. Nyní je tedy čas na představení obsahové analýzy, díky níž je možné diskurzivní praktiky nejen zachytit, ale analyzovat je v kontextu jejich řetězení.

\section{4. „Islám“ versus „národ“ - analýza krok po kroku}

\section{a. Korpus a výskyt sledovaných výrazů}

Obsahová analýza není jasně ukotvený analytický nástroj, nicméně jde převážně o kvalitativní prústup při práci s obsahem datového korpusu za účelem intepretace (Hsieh a Shannon 2005: 1277). Jednotlivé typy obsahové analýzy se liší podle kritérií výběru datového korpusu, způsobu kódování, rozsahu kódování, popř́padě určení kritérií dle teorie a kontextu (nebo kombinace obou). V tomto článku je použita sumativní obsahová analýza (viz také Hsieh a Shannon 2005: 1283-1285) s přesahem do analýzy metafor. Prvním krokem obsahové analýzy je ohraničení problému jako prŕpadové studie (Creswell 2007: 74-75). Druhým krokem obsahové analýzy je identifikace oblasti, kde získat empirických data, a takový výběr odůvodnit precizováním smyslu a podoby kritérií. Třetím krokem je vyhledání všech relevantních zdrojů dat (v tomto případě konkrétních článků), kde se objevují sledované výrazy (a zároveň zaznamenání všech těchto výrazů). Výrazy jsou vyhledávány, a tedy i určovány skrze tzv. lemmata, což jsou slova reprezentující všechny své tvary a časy (viz nap̌r. Mertl a Hejnal 2013: 148), včetně

předpon a př́pon. Čtvrtým krokem je kontextuální větvení významů vyhledaných výrazů a jejich seskupování do setů tak, aby bylo možné odhalit nutné opakující se vzory (viz např. Harper 2012: 237). Pátým krokem je klasifikace hodnotového zabarvení těchto setů tak, aby bylo jasné, jak se mluvčí (vytvářející analyzovaná data) vztahují k určenému kontextu (viz např. Adjei 2013). Šestým krokem je určení vztahu mezi významy v setech a taktéž vztahu mezi jednotlivými sety pomocí jejich schematizace do metafor, které mohou odhalit dřive opomíjené souvislosti (viz např. Maasen a Weingart 2000: 20-21). Sedmým a posledním krokem je interpretace ${ }^{12}$ a konstrukce diskurzivních praktik postavená na získaných (a dle kritérií selektovaných) empirických datech.

${ }^{11}$ Z tohoto důvodu je i výzkum marginálních skupin důležitý, protože jejich taktiky jsou relevantní pro koncept populismu obecně, i když nedosahují uplatnění a možné hegemonie - to se týká i aktérů zkoumaných v této studii, tedy Úsvitu a Bloku.

12 Při interpretaci v tomto článku je sledován postup tzv. hermeneutické spirály (Ricoeur 2000: $114 \mathrm{nn})$. 
Národní listy (dále také jen „Listy“) jsou periodikum vydávané společností Tyneside s.r.o. ${ }^{13}$ pro politickou stranu Úsvit - Národní koalice ${ }^{14}$ a spolek Blok proti islamizaci, z. s. ${ }^{15}$ Záměr vydávání tohoto periodika není politickou stranou ani spolkem explicitně deklarován, nicméně implicitně Národní listy slouží $\mathrm{k}$ periodické prezentaci názorů představitelů zmíněné strany či spolku (zda by mohl svůj př́spěvek publikovat i sympatizant strany či jinak definovaný autor není z oficiálně deklarovaných informací zř́ejmé). Z tohoto důvodu jsou Listy pro účely ověření nastolených tezí téměř ideální. Účel periodika ve smyslu sebeprezentace Úsvitu je zř̌ejmý ze skladby jmenovitě uváděných přispěvatelů, často členů této politické strany (např. Borkovcová 2016b; Burian 2016; Kozdera 2016 aj.). U většiny prríspěvků není uváděn autor, nicméně v záhlaví názvu periodika je vždy na první straně uvedeno logo politické strany Úsvit - Národní koalice a bud' logo Bloku proti islamizaci (u čísel vydávaných od 7. 6. 2016 do data odeslání tohoto článku k recenznímu řízení, tj. 28. 7. 2016) nebo logo dnes již zrušeného $^{16}$ spolku Bloku proti islámu ${ }^{17}$, a to konkrétně u čísel vydávaných do ukončení spolupráce v květnu 2016 mezi stranou s tehdejším názvem Úsvit přímé demokracie $^{18}$ a právě zmíněným Blokem proti Islámu. ${ }^{19}$ Kritéria konkrétního výběru článků jsou spojena s třetím krokem analýzy a dle kritérií je vytvořen finální datový korpus. Do datového korpusu jsou zahrnována pouze ta čísla Listů, která vznikla po dobu spolupráce Úsvitu s Blokem v době, kdy ho vedl Martin Konvička. Důvod tohoto výběru spočívá v připuštění možnosti charismatického pojetí populismu představovaného jednou výraznou osobností (díky její mediální kontroverzi), navíc působící v době vrcholící tzv. imigrantské krize. Takové zúžení vychází i z udržitelnosti výzkumu a možnosti zobecnění značného množství informací.

Druhou redukcí datového korpusu je vyloučení článků Listů, které neobsahují lemmata -islám/islam- a -národ-. Výběr článků, které naopak tato lemmata

\footnotetext{
13 Vlastní popis činnosti této společnosti viz Tyneside (2016).

14 Vlastní prezentace této politické strany viz Úsvit (2016).

15 Stanovy spolku viz Blok proti islamizaci, z. s. (2016). Spolek spolupracuje se stranou Úsvit Národní koalice, což je patrné jak z Národních listů (viz níže), tak z odkazu na tuto stranu na stránkách spolku. Podle výpisu z Rejstř́ku politických stran a politických hnutí by mohl spolek spolupracovat i s politickou stranou DOMOV s BLOKEM PROTI ISLAMIZACI. Personální propojení s již zaniklým Blokem proti islámu je patrné zejména v osobě Jany Volfové, bývalé místopředsedkyně tohoto spolku (viz např. Idnes.cz 2016). Pro výpis proměn názvu politické strany viz MVČR (2016a).

16 Z veřejně dostupných zdrojů viz např́íklad Idnes.cz (2016).

17 Odkaz na webové stránky, obsažený v logu Bloku proti islámu, tj. www.blokprotisilamu.cz je automaticky přesměrováván na spolek Blok proti islamizaci.

18 Oficiálně je název Úsvit - národní koalice platný od 19. 8. 2015. Ke změnám názvů této strany viz Rejstř́k politických stran a politických hnutí (MVČR 2016b).

19 Všechny články vydané $\mathrm{v}$ této době již není možné stáhnout přes oficiální webové stránky Úsvitu. Články byly staženy ještě před jejich odstraněním, a to 25. 4. 2016.
} 
obsahují, je realizován skrze automatický záznam výskytu zkoumaných lemmat pomocí softwaru MaxQda (verze 11). Lemmata jsou díky tomu roztříděna a v datovém korpusu jsou ponechány pouze ty články, které prokazatelně hledaná lemmata obsahují. Nutno dodat, že všechny články jsou ve formátu .pdf a bylo u nich provedeno automatické rozpoznávání textu (tzv. funkce OCR). Rozpoznání veškerého textu bylo ještě následně zkontrolováno ručně, aby nedošlo k vyloučení žádného článku $\mathrm{z}$ automatického vyhledávání lemmat. Zkoumaná lemmata -islám/islam- se vyskytla v počtu 501. Lemmata výrazu národ- se objevila 139krát. Po automatickém kódování byly kódy (a zprostřredkovaně články) ještě selektovány dle následujících kritérií: Byly odstraněny kódované pasáže, které se vyskytovaly v názvech (typicky se jednalo o názvy Blok proti islámu a Národní listy); byly odstraněny záznamy vyskytující se v adresách či označeních bez souvislosti se sledovaným tématem (např̀ výraz Národní dům); byly odstraněny záznamy, které označovaly slova bez kontextuální souvislosti ke zkoumanému (jednalo se převážně o slovo mezinárodní v neutrálním významu); byly odstraněny záznamy u článků, které byly přetiskovány opakovaně $\mathrm{v}$ dalších číslech (to se týkalo zejména regionálních mutací Národních listů, kde převládal celorepublikově standardizovaný obsah). Články, které obsahovaly přetištěné pasáže, ale titulek článků byl jiný, byly ponechány (viz také závěr této studie). Výsledkem selekce byla konečná suma 126 výskytů lemmatu -islám/islam-a 29 výskytů lemmat -národ-. Články, ve kterých se selektovaná lemmata objevila, tvoří finální korpus analyzovaných zdrojů (viz níže); zároveň byly výskyty výrazů zaznamenány a evidovány pro čtvrtý krok analýzy.

Následující dvě kapitoly spojují čtvrtý, pátý a šestý krok analýzy (mimo určení vztahů mezi sety, které je součástí až následné interpretace jako sedmého a posledního kroku). Jsou to kroky nutné pro závěrečnou interpretaci a potvrzení či vyvrácení v úvodu nastolených tezí. Kontextuální větvení, seskupování výrazů do setů a hodnotové zabarvení zkoumaných výrazů bude v následujících kapitolách rozděleno na dva úseky, tak, aby mohl být věnován samostatný prostor každému z klíčových sledovaných výrazů, tedy výrazům -islám/islam-a -národ-. $\mathrm{Na}$ tomto místě je nutné znovu upozornit, že lemmata byla plně určující: Pokud se v nějakém článku Listů objevuje např́lklad výraz, ,imigrace“ či „,imigrant“ bez jakéhokoliv kontextuálního spojení s islámem (-islám/islam-), je kontext záměrně ignorován, protože by byly znehodnoceny výsledky vưči sledovaným kritériím uvedeným výše. 


\section{b. Výraz-islám/islam-}

Výraz islám (-islám/islam-) se ve sledovaném korpusu objevuje v několika spojeních, ${ }^{20}$ která jsou předmětem analýzy. Spojení vytvářejí kontext a ze všech uvedených kontextů jsou vytvořeny kontextuální sety, které respektují prvotní význam vtělený do vytvořených metafor. Tento význam bude $\mathrm{v}$ následujících odstavcích prověřován na základě doplnění hodnotových vyjádření a rozvíjení kontextu skrze obsah celých vět a popř́ípadě odstavců. Díky tomu může dojít nejen k ověření, ale i ke korigování prvotního možného zjednodušení, navíc může dojít i k odhalení významového propojení dvou zdánlivě nesouvisejících oblastí (což je typické pro metafory). Před prověřováním ale musí dojít k samotnému stanovení setů.

${ }^{20}$ Konkrétně se jedná o tato spojení (řazeno dle abecedy): Agresivní náboženství islám (Redakce NL 2016a, 2016d, 2016p; Redakce NL a Konvička 2016a); Důležitost islámu (Klímková 2016); Historické zkušenosti s islámem (Redakce NL a Konvička 2016b); Ideologický pramen islámu Korán (Redakce NL 2016a, 2016d; Redakce NL a Konvička 2016a); Islám a krutý boj proti nevěŕícím (viz širší kontext) (Klímková 2016); Islám není rasa (Redakce NL a Konvička 2016b); Islám je cizí (Redakce NL a Konvička 2016a); Islám je ideologie (Borkovcová 2016b; Klímková 2016; Kocourková 2016); Islám je kultura (Klímková 2016; Redakce NL a Konvička 2016a; Svoboda 2016); Islám je životní filozofie (Redakce NL a Konvička 2016a); Islám je mimo zákon (Kocourková 2016); Islám šiří náboženskou nesnášenlivost (Redakce NL a Konvička 2016a); Islám širíi nenávist (Redakce NL 2016v, 2016z); Islám zapouští kořeny (Kocourková 2016); Islamizace Evropy (Redakce NL 2016a, 2016s); Islamizace naší země, ČR (Redakce NL 2016a, 2016m, 2016x); Islámofobie a islamofobie (Redakce NL 2016a; Redakce NL a Konvička 2016b); Islámská diktatura (Redakce NL, Kohout 2016); Islámská imigrace a islámský imigrant (Bakala 2016; Redakce NL 2016s); Islámská invaze (Koller 2016); Islámská komunita (Borkovcová 2016a; Redakce NL 2016p, 2016x); Islámská obec (Borkovcová 2016a; Redakce NL 2016i, 2016p, 2016v, 2016x); Islámská rodina (Burian 2016); Islámská země (Redakce NL 2016s); Islám není etnikum (Redakce NL a Konvička 2016a); Islámské náboženství (Klímková 2016; Kocourková 2016; Redakce NL 2016p, 2016x; Redakce NL a Konvička 2016a); Islámský duchovní (Redakce NL 2016v); Islámský fanatismus (Redakce NL a Kohout 2016); Islámský radikalismus (Redakce NL 2016p, 2016v, 2016x; Redakce NL, Kohout 2016; Redakce NL a Konvička 2016b); Islámský rituál halal (Redakce NL 2016i, 2016p, 2016q, 2016x); Islámský stát (Redakce NL 2016c, 2016g, 2016j, 20161, 2016v, 2016v, 2016y, 2016aa; Redakce NL a Kohout 2016; Redakce NL a Konvička 2016b); Islámský terorismus (Redakce NL 2016p, 2016x); Kritici islámu (Redakce NL a Konvička 2016b); Moc islámu (Borkovcová 2016b); Nebezpečnost islámu (Redakce NL a Konvička 2016a); Nelibost, odpor či nenávist k islámu (Redakce NL 2016a, 2016x, Redakce NL a Konvička 2016a, 2016b); Obrana a ochrana před islamizací (Redakce NL 2016j, 2016p); Praktiky islámu (Redakce NL 2016d); Problém islamizace (Redakce NL 2016p); Problematika islámu (Redakce NL a Konvička 2016a); Středověké chápání islámu (Redakce NL a Kohout 2016); Střet s islámem (Redakce NL a Konvička 2016b); Śířní (expanze) islámu (Redakce NL 2016q; Redakce NL a Konvička 2016b); Utlačování islámských žen a ženy v islámu (Kocourková 2016; Redakce NL a Kohout 2016); Vymezení se vůči islamizaci (proti islamizaci) (Redakce NL 2016r, 2016w); Zastavení islamizace (Redakce NL 2016j); Zaujatost k islámu (Procházková 2016). 
První set tvoři metafora ISLÁM JE NÁBOŽENSTVII ${ }^{21}$ a obsahuje výrazy, jako jsou agresivita, rituál halal, nesnášenlivost a duchovní (představitel). Druhou metaforou je ISLÁM JE TÉMA. Na tuto metaforu jsou navázány př́ćciny toho, proč by měl být islám tématem objevujícím se v politickém prostoru. Mezi př́ćiny tematizace islámu lze počítat následující: Islám je dưležitý; s islámem se pojí moc; islám má své praktiky; islám je kultura; a islám je životní filozofie. Třetí metaforou je ISLÁM JE PROCES. Obsah třetí metafory je vztažen k islamizaci jako procesu přeměny z „ne-islámu“ na ,islám“, obsahující slovní spojení jako zapouštění kořenů; invaze; imigrace; přeměna Evropy; přeměna České republiky; vymezení se vůči procesu islamizace jako problému, a to ve formě snahy o zastavení islamizace a ochrany před ní. ISLÁM JE IDEOLOGIE je v pořadí čtvrtou metaforou, která se dle uvedených kontextů pojí pouze s Koránem jakožto deklarovaným zdrojem islámské ideologie. Pátou metaforou je ISLÁM JE CIZÍ. Do této metafory je možné zařadit kontext islámu stojícího mimo známé a přijímané prostř́edí (ve smyslu sociálního stavu a sociální reality vnímané diskurzivním společenstvím Listů). Neznámé a nepřijímané následně vyvolává nelibost; odpor; nenávist (např. z důvodu utlačování žen islámem); šíření nenávisti islámem (např́iklad proti nevěŕícím); obavy z radikálnosti a teroristického potenciálu díky fanatismu islámu. To, že je islám cizí, se také může vázat na historické zkušenosti s islámem, středověké chápání islámu a ve výsledku islámofobii. ${ }^{22}$ Poslední (šestou) metaforou je ISLÁM JE SYSTÉM. S touto metaforou se pojí výrazy jako diktatura; obec; rodina; země; a islámských stát. Všechny tyto výrazy asociující celky s vlastním funkčně propojeným systémem. Nyní přejdu k označení hodnotového zabarvení (nejen) v opakujících se vzorech.

Set zastoupený metaforou ISLÁM JE TÉMA otevírá možnost uchopení islámu nikoliv již jako výrazu s pouhým kontextuálním zasazením, ale jako skutečného hodnotově zabarveného „tématu“ Listů s nějakým konkrétním sdělením. Islám je důležitý, protože se týká nevěřících a nemuslimů (a týká se tedy i nás). Důležitost tématu je dána negativním vymezením vůči muslimům a jejich kultuře, kterou bychom se měli zabývat (Klímková 2016), protože se jedná o kulturu a životní filozofii odlišnou od té naší (Redakce NL a Konvička 2016a). Odlišná kultura by např́ílad mohla ohrožovat naše školství (Svoboda 2016). ${ }^{23}$ Ohrožení „...ilustruje nejlépe příběh ze sousedního Ústeckého kraje, kdy učitel střední zdravotnické školy čelil vyhrožování islámské rodiny, jejíž dceru nenechal

\footnotetext{
${ }^{21}$ Kapitálky se (kvůli přehlednosti textu) pro metafory a jejich analýzu používají běžně, nicméně není to automatické pravidlo (Lakoff a Johnson 2002; Lakoff 2004).

${ }^{22} \mathrm{~V}$ Listech je používán i výraz „islamofobie“.

${ }^{23}$ Celé znění krátkého článku: „V době, kdy uprchlíci nechtějí často respektovat naši kulturu a dokonce ohrožují naše školství, je sport pro děti strašně důležitý. A speciálně hokej je pro nás nadějí, jak v mladé generaci budovat národní, ale i třebíčskou hrdost, které je nejlepši lékem, jak ubránit Česko před islámskou kulturou“" (Svoboda 2016).
} 
odmaturovat“ (Burian 2016; viz také Procházková 2016). ${ }^{24}$ Dalším důvodem, proč je dobré se islámem zabývat, je jeho stoupající moc díky prúíchodu ilegálních imigrantů do Evropy, viz např. ,,[s] př́chodem ilegálních imigrantů sillí moc islámu v Evropě “ (Borkovcová 2016b). Islám je spojen s migrací jako problémem a migranti jsou spojeni s islámem. Navíc je téma důležité proto, že imigrace je spojena s ilegalitou a ilegalita je vnímána jako problém, který by měl být nastolen s cílem nalézt řešení. Islám a jeho praktiky jsou zaznamenáníhodné jako společenské a politické téma (Redakce NL a Konvička 2016a). Téma by ale nemělo být jen nastoleno, nýbrž i diskuze o něm by měla být otevřená, protože vưči obsahu islámu by měla být připuštěna kritika (Redakce NL 2016d; implicitně také Redakce NL a Konvička 2016b).

Dle uvedeného je islám důležité téma, protože se nás týká. Islám je odlišný, může nás ohrožovat (viz také níže) a jeho moc sílí společně s příchodem imigrantů. Tím se rozbíhá proces islamizace (ISLÁM JE PROCES), který je reálný, faktický (viz Redakce NL a Konvička 2016b). Otázka přímého vyhánění islámských imigrantů je otevřená, ale je třeba na takovou možnost upozornit, ${ }^{25}$ dráždit pražskou kavárnu a vysmívat se naivním intelektuálům (Redakce NL 2016s). Imigrace není jakýsi intelektuální problém odtržený od reality, ale problém praktický a reálný (což je vysloveno v souvislosti s odmítnutím naivity). Před imigrací bychom se měli prakticky chránit a bránit, a to nejen ochranou hranic, ale i výchovou vzdělané a hrdé generace (Redakce NL 2016j) a demonstracemi (Redakce NL 2016r 2016w), protože islám je nebezpečný (Redakce NL a Konvička 2016a). Problémem ale je, že v souvislosti z kriminalizací Martina Konvičky je vůbec otázkou, „...zda je v této zemi legální bránit se islamizaci“ (Redakce NL 2016p). Chránit se (a bránit se) je ale nutné, protože islamizace postupuje a „... islám zde $\mathrm{v}$ Evropě zapouští kořeny ve svém nejhorším provedení a postoj našich europoslanců je vlastizrádný“ (Kocourková 2016). Islamizaci je třeba zastavit, a to prostřednictvím voleb, ve kterých by byla zastavena současná probruselská a proimigrační vláda (Redakce NL 2016m). „Úsvit s Blokem proti islámu udělá vše, aby zastavil islamizaci ČR" (Redakce NL 2016x). Další možností je apelovat na obranu před islámskou invazí prostřednictvím iniciativ, jako je Stráž obrany státu (SOS), která nebude ozbrojená, nebude stranickou formací a měla by fungovat dle vzoru dobrovolných hasičů: „Vzhledem $\mathrm{k}$ tomu, že podle ministerstva vnitra vázne nábor zaměřený na posílení především počtu uniformovaných policistů v terénu, může se SOS stát složkou, je problém do určité míry eliminuje“ (Koller 2016). ${ }^{26}$

\footnotetext{
${ }^{24}$ Termín rodina je zde užit v jiném kontextu, než bylo původně předpokládáno, a proto je tento termín vyřazen ze setu ISLÁM JE SYSTÉM (kam byl původně zařazen).

${ }^{25}$ Naprríklad pomocí symbolu vikinského bojovníka při sportovní události: ,„již v loňském roce při zápase Viktorky domácí fanoušci předvedli choreo vikinského bojovníka, který stál nad Evropou a vyháněl islámského imigranta“" (Bakala 2016).

${ }^{26}$ Poznámka: citováno doslovně, kontext není zcela patrný.
} 
Je třeba se bránit islamizaci, protože islamizace může vytvořit negativní systém (ISLÁM JE SYSTÉM), který nahradí stávající kulturu Evropy a České republiky. Např́klad z Británie může být v roce 2050 islámská země (Redakce NL 2016s). Islámský kulturní systém může nabývat rozměrů diktatury, pokud ztratíme ekonomickou sílu se proti němu bránit. Kohout (2016) tuto analogii vidí v možné islamizaci Turecka, které by následně existenčně ohrožovalo ekonomicky nestabilní Řecko. Dále je třeba bránit islámským obcím (ve smyslu komunit), aby verbovaly islámské radikály např́klad ve věznicích. Duchovní je třeba prověřit, protože islámské obce získávají peníze mj. z poplatků z porážky halal, které mohou být použity na financování terorismu (Borkovcová 2016a; Redakce NL 2016p) a jeho šiření (Redakce NL 2016q). Prověřování je otázkou prevence před šířením islámu jako systému skrze komunity, které $\mathrm{v}, \ldots$,..ČR rostou nejen v Teplicích, Praze, Brně..." (Redakce NL 2016x). Samostatným problémem, i když s islámem jako systémem souvisí, je tzv. Islámský stát. Islámský stát je (v kontextu Listů) oproti islámským duchovním prímo spojen s terorismem, který Evropu ohrožuje, protože podle šéfa německé rozvědky „....nejméně jeden ze sta uprchlíků [je] terorista Islámského státu s prýkizem zabíjet..." (Maassen dle Redakce NL 2016c, viz také 2016j). Imigrace je prŕímo spojena s Islámským státem a Islámský stát s terorismem. Islámský stát je hrozba, před kterou se musíme (my, Evropa) zachránit (Redakce NL 2016g). Hrozba je situována do Turecka, protože pokud bude realizován bezvízový styk Turecka s Evropskou unií, bojovníci Islámského státu budou moci prijít do Evropy bez větších obtíží. Měli bychom se bránit jako Velká Británie, a to vystoupením z Evropské unie v prŕípadě, že $\mathrm{k}$ přijetí politiky bezvízového styku s Tureckem dojde. Následně bychom mohli zrídit Pohraniční policii pro dlouhodobou ochranu hranic (Redakce NL 20161). ${ }^{27}$

Výrazy islámská obec a islámská komunita (včetně duchovních) přivádí pozornost $\mathrm{k}$ islámu jako $\mathrm{k}$ náboženství (ISLÁM JE NÁBOŽENSTVÍ). Rituál halal byl již zmíněn jako možný zdroj financí pro islámskou obec. Rituál je prováděn následovně: „,..zviŕre [je] pomalu usmrcováno za plného vědomí tak, aby do poslední chvíle slyšelo modlitbu Alláhovi, kterou pronáší muslimský duchovní imám. Maso halal můžeme už dnes naprosto běžně vidět v supermarketech. Při představě, že jatka, která halal porážku provádí, jsou v Nýranech, Korytách - pouhé $3 \mathrm{~km}$ od Klatov i na Tachovsku, tuhne krev v žilách“ (Redakce NL 2016i). Financování muslimských obcí je chápáno jako hlavní problém, vedle vedlejších problémů nehumánního zabíjení kuřat a rizika nedodržování hygienických předpisů (Redakce NL 2016q). Pokud je islám možno chápat jako náboženství, je otázkou, zda je to náboženství agresivní a nesnášenlivé vưči ostatním. Na této otázce se ale odborníci neshodnou (podobný kontext je

27 „Jaké síly budeme mít v záloze, když teroristé Islámského státu zaútočí zároveň na vícero místech tak, jak tím vyhrožují? Prostě potřebujeme armádu, její zálohy a 3000 nových policistů s technologiemi pro dlouhodobou ochranu hranice a dostatečné záložní síly“ (Redakce NL 2016aa). 
uveden u všech těchto zdrojů, některé jsou částečným přetiskem identických informací Redakce NL 2016a, 2016d, 2016p; Redakce NL a Konvička 2016a). Podle Konvičky se ale jedná o náboženství širíící nenávist (Redakce NL 2016y; identicky viz 2016z; srov. Redakce NL a Konvička 2016a). Podle Klímkové islám z větší části pojednává o krutém boji proti nevěřícím. V tomto prrípadě ale Klímková nespojuje islám s náboženstvím, ale př́mo jej označuje za ideologii (ISLÁM JE IDEOLOGIE). Ideologii samotnou chápe jako neslučitelnou s lidskými právy (Klímková 2016). Kocourková pak o islámu tvrdí, že to není náboženství, ale zrůdná ideologie, která popírá základní lidská práva pro ženy (viz také Redakce NL a Kohout 2016) a zaujímá silně negativní postoj k jinověrcům, kteří „...mají být zabiti“ (Kocourková 2016). Nositeli islámu jako ideologie jsou ilegální migranti (Borkovcová 2016b). Hlavním ideologickým pramenem islámu je Korán (Zouhar dle Redakce NL 2016a; a identicky dle 2016d; Redakce NL a Konvička 2016a).

Závěrečnou metaforou, kterou je třeba prověrit, je metafora ISLÁM JE CIZÍ. Tento set je zařazen až jako poslední z toho důvodu, že obsahuje obecnější vyjádření, která se týkají negativního vymezení, ale která nebylo možné jednoznačně zařadit do jiných setů. Výhodou obecnosti může být možnost propojení výše uvedených kontextů, do jisté míry separovaných v samostatných setech. Cizost islámu je spojována s odlišností (konkrétně kultury) (Redakce NL a Konvička 2016a). Odpor vůči islámu je celosvětový a Evropané nejsou v odporu nejaktivnější - aktivnější jsou ty kultury, které mají s islámem historické zkušenosti. Mezi takovými kulturami a islámem dochází ke střetům (Redakce NL a Konvička 2016b). ${ }^{28}$ Islám je tak špatný sám o sobě a je cizí všem ne-islámským kulturám. Islám by měl být postaven mimo zákon (Kocourková 2016). S islámem je také explicitně spojen fanatismus (Redakce NL a Kohout 2016) a radikalismus (Redakce NL 2016p). V Listech naopak není uváděno explicitní spojení islámu a terorismu, spojení je pouze implicitní, a to skrze Islámský stát.

Z výše jmenovaných kontextů byla při větvení do setů dle generativních metafor vyřazena spojení: islám není rasa; islám není etnikum; středověké chápání islámu; a islámofobie. Důvodem vyřazení je absence kontextuální souvislostí těchto spojení s ostatními kontexty a celková nejasnost jejich smyslu a významu při jejich prověření v konkrétních článcích Listů.

\section{c. Výraz -národ-}

Výraz -národ- je ve sledovaném korpusu méně frekventovaný, ${ }^{29}$ než výraz -islám/islam-. Pro větvení z korpusu získaných výroků u sledovaného výrazu je

\footnotetext{
${ }^{28}$ Spojení střet s islámem bylo přidáno k setu ISLÁM JE CIZÍ dodatečně.

${ }^{29}$ Konkrétně se objevuje $\mathrm{v}$ těchto kontextech (řazeno dle abecedy): Celý národ; celonárodní (Redakce NL 2016e, 2016ab); Český národ (Redakce NL 2016f); Evropský národ (Toepfer 2016); Mezinárodní ochrana (Kozdera 2016); Nadnárodní korporace (Redakce NL 2016t); Národ
} 
zvolen stejný postup, jako u výroků pojících se $\mathrm{k}$ výrazu -islám- v předchozí kapitole. První set je vyjádřen skrze metaforu NÁROD JE IDENTITA, kam jsou zařazena slovní spojení český národ; evropský národ; národní pravomoc; vztah národa k vlasti; a nenávist $\mathrm{k}$ národu. Druhý set spadá pod metaforu NÁROD JE CHARAKTER. Do tohoto setu jsou zařazena spojení: národ bojovníků; národ poserů; národ Švejků; a národní hrdost. Třetí a předposlední metaforou tvořící specifický set je MEZINÁRODNí NENÍ NÁRODNÍ, kam spadají výrazy mezinárodní ochrana a nadnárodní korporace (k výrazu mezinárodní viz i poznámka výše $\mathrm{k}$ výběru datového korpusu). Poslední metaforou je NÁROD JE POČET. Výrazy, které se s touto metaforou pojí a tvoří tak set kontextuálně př́buzných významů jsou: celý národ (celonárodnî); půlka národa; a většina národa. Výrazy, které nebyly zařazeny do žádného setu, ale přesto se v datovém korpusu objevují, jsou dva, a to národnost a národní sebevražda. Vzhledem ke kontrole řazení do setů bude prověřeno, zda tyto výrazy nepatř́ do nějakého ze setů, popřípadě zda nevytváŕí vlastní specifický set ojedinělého kontextu. Nyní dojde k označení hodnotového zabarvení (nejen) v opakujících se vzorech.

$\mathrm{K}$ určení hodnotového zabarvení skrze kontext u výrazu -národ- se nabízí začít s metaforou NÁROD JE IDENTITA, protože ta může (ale také nemusî) určit význam výrazu národ ukrytý v Listech. Díky tomu by bylo možné jen prriřazovat dílčí významy navázané na tento základní výraz. Český národ navazuje na odkaz Přemyslovců a především na Elišku Přemyslovnu, jako matku otce vlasti. Český národ má svou kontinuitu a tato kontinuita je připomínána jen málo (Redakce NL 2016f). V současnosti se projevuje ztráta vlastní identity, protože nastupuje identita evropská, která je tvořena Evropskou uniŕ. Takový proces je dramatický a nebezpečný. Evropská identita je negativní, protože se vyznačuje tolerancí na úkor odpovědnosti $\mathrm{v}$ souvislosti se současnou pseudohumanitou. Národní identita musí být předávána z rodičů na děti, pokud již na to nestačí školy. Pokud se tak nebude dít, národ zanikne a s ním zanikne i kultura. Národ musí mít vztah k vlasti, která přestavuje zem a kořeny symbolizované rodiči a prarodiči (Toepfer 2016). Vhodným opatřením pro uchování národní identity může být udržení výsostné pravomoci udělování azylu imigrantům na úrovni národního státu, nikoliv přenos této pravomoci na úroveň Evropské unie, jak navrhuje Evropská komise (Redakce NL 2016k).

Druhou metaforou je NÁROD JE CHARAKTER. Národ má hrdý charakter, tedy národ jako celek je nebo má být hrdý. Národní hrdost by měla být podporována a souvisí se znalostí vlastní historie. Pro podporu národní hrdosti by

bojovníků (Redakce NL 2016p); Národ poserů (Kuras 2016); Národ Švejků (Redakce NL 2016p); Národní hrdost (Adamec 2016; Hanzl 2016; Redakce NL 2016h, 2016v; Svoboda 2016); Národní identita (Redakce NL 2016f, 2016o, 2016v, 2016x); Národní pravomoc (Redakce NL 2016k); Národní sebevražda (Redakce NL 2016y, 2016z); Národnost (Kozdera 2016); Náš národ (Redakce NL 2016f); Nenávist k národu (Redakce NL 2016a); Půlka národa (Redakce NL 2016a); Většina národa (Redakce NL a Konvička 2016a); Vztah národa k vlasti (Toepfer 2016). 
mělo být děláno maximum, $\mathrm{v}$ kontrastu s nesmyslnou snahou o budování multikulturní společnosti podporovanou z evropských dotací. Problém se týká především regionálního školství (Adamec 2016). Národní hrdost ${ }^{30}$ lze posilovat i terénní prací, která by měla být založena na péči o děti ze sociálně vyloučených lokalit. V Libereckém kraji by bylo dobré postavit minimálně osmnáct takových center. Vedle center by se měly podporovat tábory, hudební a taneční festivaly pro děti, které „...ukazují dětem, že nezískají nic zadarmo, že vše záleží na nich samotných, a probouzejí v nich národní hrdost“ (Hanzl 2016). Financování by mohlo být pokryto úsporou díky omezení financování tzv. multikulturních dotačních titulů, jako byl např́klad terénní průzkum společnosti Člověk v tísni v romských ghettech, kde se dětí ptali na to, čím by chtěly být (Hanzl 2016). Multikulturní programy by měly být zastaveny, a naopak by měla být zavedena výchova $\mathrm{k}$ národní hrdosti na školách. To je oficiálním bodem programu Úsvitu a Bloku v krajských volbách (Redakce NL 2016h). Prostředkem podpory národní hrdosti je také zastavení inkluze (Redakce NL 2016v). Co bychom naopak měli podporovat je bojovnost, nikoliv švejkování (Redakce NL 2016p) s čímž souvisí, že se musíme přestat ,...vvnímat jako národ poserů a předposerů a vracet se k oslavování hrdinů. Legie, královské letectvo, heydrichiáda, taky třeba zpětně Radetzky, Žižka, Přemysl Otakar, ale taky gigantické intelekty jako Komenský, Mendel, Wichterle, Heyrovský..." (Kuras 2016). Na témže místě jsou zmiňováni i podnikatelé jako Bat’a, Škoda, Jelínek, nebo i rabbi Loew.

Dalši set MEZINÁRODNÍ NENÍ NÁRODNÍ je vymezením národního prostoru, který máme právo kontrolovat a ovlivňovat, $\mathrm{v}$ protikladu k mezinárodnímu prostoru, který nás ovlivňuje, nicméně nám byla vzata možnost jej změnit $\mathrm{v}$ př́padě, pokud s ním nesouhlasíme. Jako př́klad je uvedeno znásilnění dívky v Pardubicích, kdy měli tento čin spáchat blíže neurčení cizinci (není uvedeno, zda se jedná či nejedná o imigranty). Pokud by byli cizinci odsouzeni, pak i přesto mohou získat azyl, pokud by o něj zažádali. Azylový zákon se řídí mezinárodními dohodami, které by byly porušeny $\mathrm{v}$ prípadě změny našeho azylového zákona směrem ke zpř́ísnění (v podobě znemožnění získání azylu pro odsouzené). Výjimkou, kdy by cizinci nemohli získat azyl, a prritom bylo nedošlo k porušení mezinárodních dohod, by bylo spáchání zločinů proti lidskosti či válečných zločinů (Kozdera 2016). Odmítnutí „mezinárodního“ se projevuje i v podnikatelské sféře, kdy současný establishment není schopen usnadnit administrativu českým podnikatelům. „Pobočky mezinárodních korporací vykazují rekordní zisky a tisíce českých podnikatelů končí“ (Redakce NL 2016t). Měli bychom odmítnout postup proti imigrantům a nepáchat národní

${ }^{30}$ Není vyloučeno ani posilování lokální hrdosti (viz Svoboda 2016). 
sebevraždu ${ }^{31}, \ldots$ v objetí s madam Merkelovou“ (Redakce NL 2016y; identicky viz 2016z).

Posledním setem je NÁROD JE POČET. Nás, národ, je třeba nějakým způsobem vyč́slit. My, jako celý národ, se nenecháme obelhávat Sobotkou ohledně imigrantů (Černoch dle Redakce NL 2016e), jako celý národ máme také rozhodovat v celonárodním referendu o prijímání imigrantů (Redakce NL 2016ab). Pokud kritizujeme islám jako agresivní náboženství, neměla by být tato kritika kriminalizována, protože jinak by před soudem musela stát pưlka národa (Wagnerová dle Redakce NL 2016a). S islámem se většina národa nemůže nikdy ztotožnit (Pelikánová Redakce NL a Konvička 2016a).

\section{d. Národní listy bez národa a s,nejasným" islámem. Intepretace analytických zjištění}

Šest provázaných analytických kroků přineslo několik základních zjištění, která jsou interpretována ve třech etapách. První zohledňuje tematizaci islámu a národa, druhá se věnuje zachycení procesů souvisejících s těmito tématy a ve třetí fázi je věnován prostor tzv. cílovým stavům, před kterými by se měl český národ bránit, př́padně určujícími, co by měla česká identita obsahovat.

(1) Islám je závažnější téma než téma národ. Prvním důvodem je jeho více než čtyřnásobný výskyt ve všech článcích Listů sledovaného období. Druhým důvodem je, že islám je chápán jako ohrožení národa, které je akutní, protože moc islámu stoupá a islám začíná v konkrétních prrípadech ohrožovat národ, naprŕíklad ve školství nebo ekonomice. Islám je spojen s migrací a migrace je spojena s ilegalitou. Nejdřive je tedy nutné řešit islám, aby byl národ jako takový zachován, př́padně alespoň neohrožován. Národ je identita, a tato identita je národní - tato tautologie je v Listech př́tomná. Český národ má identitu a český národ tedy existuje, protože navazuje na historii svého národa, který je jiný, než národ tvořený Evropskou unii. ${ }^{32}$ Český národ je humanitní a kulturní, protože je odlišný od konstruktu národa Evropské unie. Islám jako životní filozofie a kultura český národ ohrožuje. My jsme český národ, který je hrdý, hrdinský a bojovný, a máme svou identitu, která je v ohrožení ze strany islámu, jehož šíření je umožněno ze strany národa Evropské unie. Výsledkem je, že národ má dobrou (hrdinskou, hrdou, bojovnou, kulturní a humanitnî) identitu, o jejímž obsahu ale není v Listech nic konkrétního zmíněno. Dalším ohrožením české identity je kultura a filozofie islámu, která sílí kvưli imigraci. Islám je hrozba a identita Evropské unie je tématem, které slouží jako negativní referenční rámec vůči pozitivnímu formování českého národa ve smyslu jeho identity (bez konkrétního obsahu).

31 Původně nezařazené spojení národní sebevražda bylo přiřazeno k setu MEZINÁRODNí NENÍ NÁRODNÍ, zatímco výraz národnost nebyl dodatečně zařazen do žádného setu (srov. Kozdera 2016).

32 Národ tvořený Evropskou unií je v Listech odlišován od národa evropského. 
Implikace takového shrnutí jsou následující: Národ (zde český) má nejasný význam; snaha o formování jeho obsahu (nikoliv tedy obsah sám) je závislá na islámu, ale pouze sekundárně, protože primárně je závislá na identitě Evropské unie jako negativním předobrazu. Tematizace islámu a národa odpovídá populistickým znakům, protože vymezuje dva světy, které stojí proti sobě, přičemž jeden je dobrý (český) a druhý špatný (islámský). Jeden svět nás reprezentuje (český) a jiný svět (třetî) Evropské unie umožňuje světu islámskému hájení jeho zájmů (a proto nehájí naše zájmy). Je vytvořena specifická mentalita zlého okolí českého národa, které nereprezentuje naše zájmy a proti těmto zájmům vystupuje. Populistickým znakem také je, že datový korpus nenabízí žádný konkrétní obsah národa. Pojem národ je vyprázdněný.

(2) Islám je životní filozofie a kultura, která nás ohrožuje. Ohrožení je procesem, který zavádí vlastní systém v rozporu s českou identitou. Tento systém může být diktaturou, projevuje se rituály, které jsou děsivé, nehumánní a nehygienické, ale především generují peníze pro podporu islámské komunity ve smyslu islámské obce. Šíření této kultury je spojeno s imigrací. Imigrace je spojená s Islámským státem a Islámský stát je spojen s terorismem. Proti takovému procesu islamizace se musíme bránit sami, my Češi, tedy držitelé české identity, a to podporou české hrdosti, aktivní obranou, demonstracemi, starostí o ekonomiku a také volbami, skrze které bychom mohli vyměnit establishment Evropské unie a České republiky, který Evropskou unii podporuje a tím zabraňuje, aby pravomoci českého národa zůstaly českému národu. Klíčová je výchova k národní hrdosti (jako atributu české identity), k jejímuž obsahu ale není uvedeno nic konkrétního - pouze to, že má být vštěpována (výchovou) mj. skrze hokej a historii, a to na základě potlačení inkluze a multikulturních programů.

I v př́padě zohlednění procesu v rámci druhé fáze interpretace je tedy patrná absence konkrétního vyjádření ohledně obsahu termínu národ. Populismus je v tomto prípadě obsažen nejen ve vymezování se vưči establishmentu, ale i v apelech na instituci referenda, které má vrátit (ztracenou) reprezentaci nám, národu. Je patrné, že populismus obsažený $\mathrm{v}$ Listech odpovídá populismu vázanému na demokratické společnosti a v nich působícímu. Jiné než demokratické prostředky zabránění šiř́ení islámské kultury a životní filozofie nejsou $\mathrm{v}$ Listech uvedeny, i když z výše rozpracované teoretické perspektivy lze spekulovat nad tím, zda by instituce referenda reálně existující demokracii v České republice $\mathrm{v}$ důsledku neoslabila, protože nejsou zohledněny dopady zavedení takového prvku do demokratického systému reprezentativního charakteru.

(3) Třetím krokem interpretace jsou cílové stavy. Pokud je islám největší hrozbou, otázkou je, jaký má obsah. Prozatím byl označen za kulturu a životní filozofii. Islám lze označit i za náboženství, ale pouze pokud jsou rituál halal a zmínka o duchovním představiteli dostačujícími podmínkami pro takový krok. Tato otázka jde ale za rámec tématu této studie. Islám je označen za náboženství, ale také za ideologii. V obou př́padech nejsou výrazy blíže upřesněny, nicméně 
vyznění mají společné. Islám popírá lidská práva, je agresivní, fanatický, radikální, zrůdný a je spojen s imigranty. Zdrojem islámu je Korán. Díky této charakteristice je islám českému národu (včetně českého práva) cizí a měl by být postaven mimo zákon. Islám je dokonce podle Listů cizí všem kulturám, i kultuře evropské. Co islám vlastně je není explicitně stanoveno, protože nemá v Listech konkrétní obsah (kromě jednoho rituálu a zmínky o Koránu). Přidružené povrchní charakteristiky určují postavení islámu vưči českému národu: Islám je zlo pro český národ, protože je islám hrozbou.

Český národ je jedinečný, protože nemá identitu Evropské unie. Český národ je třeba chránit tím, že bude spoléhat sám na sebe a nebude páchat sebevraždu. Celý národ se nemá nechávat obelhávat Sobotkou a objímat se s Merkelovou, naopak má proti nim vystupovat a kritizovat je. S islámem se většina národa nikdy neztotožní, a protože síla islámu je navázána na počet imigrantů, měl by národ rozhodovat sám o sobě skrze referendum a vlastní nastavení azylové politiky. Český národ je svébytný a jedinečný, protože není tažen identitou Evropské unie. I v tomto prrípadě jde o formování pozic my vs. oni.

Islám je Národních listech explicitně označen za agresivní náboženství, ale i za negativní ideologii. Mimo těchto významů je islám charakterizován jako životní filozofie či kultura. Navzdory těmto nálepkám není z Listů jasné, co by mělo být konkrétním obsahem islámu, nicméně forma jeho užití je evidentní: jsou zachyceny pouze jeho negativní projevy vưči českému národu. Druhým dílčím, byt' nepřekvapivým, zjištěním je, že termín národ získal význam „český“. Český národ je jiný než islám a je odlišný i od identity Evropské unie (nikoliv však identity evropské). Výraz český národ nemá jednoznačně určitelný obsah, díky tomu je jeho význam nejasný, a proto jeho uživání v širším kontextu apelování Úsvitu a Bloku skrze Národní listy nese znaky ukotveného populismu.

\section{Závěrem}

Úsvit a Blok vystupují v Národních listech populisticky. Islám stylizují jako hrozbu, která jde proti české identitě a postupně sílí. Tím vyvolávají obavu z ohrožení, tuto obavu kultivují a staví se do role těch, kdo reprezentují př́slušníky hrdého a nebojácného českého národa, aniž by uvedli, co je tento národ a kdo by do něj měl patřit (jaká jsou kritéria češství? Stačí to, že nemám rád establishment, Evropskou unii a islám?). Kritéria jsou nejasná, protože v populismu o stanovení kritérií ani nejde - podstatná je forma pro tvorbu mentality. Podobně nejasná jsou i kritéria islámu, mimo Koránu jako ideologického zdroje a rituálu halal. V Listech není určeno, co má být obsahem islámu a čeho se má český národ obávat, mimo porušování lidských práv žen, která nejsou specifikována (o jaká práva se konkrétně jedná?). Islám a český národ jako pojmy a prvky diskurzivní struktury nemají jasný obsah. Vztahy mezi nimi 
jsou hodnotově negativní, což implikuje účel spočívající v tvorbě populistické mentality, která ale ve svém důsledku může popírat demokratickou pluralitu.

Populismus se v analýze Národních listů projevil vytvořením dvou světů: našeho českého světa a světa jiného (zahrnujícího svět identity Evropské unie a svět islámu). Tím byl naplněn jeden z rysů populismu. Mezi těmito světy se nachází český establishment (vláda v čele se Sobotkou), který se vzdaluje české identitě, protože hájí ,jejich“, nikoliv „naše“ zájmy. Úsvit a Blok se snaží stavět do role nové elity, která bude stát po našem boku, čímž vytváŕí specifickou populistickou mentalitu, která však stojí na nekonkrétních termínech a př́slibu větší moci pro voliče skrze referendum o imigraci. Podmínky referenda nebyly tématem této analýzy; nicméně lze říci, že ve vztahu k islámu a následně k imigraci jsou v Listech formulovány nejasně a heslovitě. Jediným populistickým prvkem, který nebyl ve sledovaném výseku prokázán, je charisma představitelů. Zde by nicméně byla zajímavá analýza vizuální stránky Národních listů, plné stylizací Martina Konvičky a Miroslava Lidinského (předsedy Úsvitu), jak se štíty s českým lvem chrání území České republiky (symbolizované mapou České republiky) před hordou imigrantů (na pozadî). Taková analýza by si však vyžadovala jinou metodu než sumativní obsahovou analýzu navázanou na kontext a metafory.

Mezi dílčí zjištění této studie patří nejasnost konkrétního obsahu termínů národ a islám ve zkoumaném obsahu Listů. Předpokladem čtenáře Listů by mohlo být, že obsah termínů národ a islám by měl být zřejmý, pokud jedním z hlavních témat Úsvitu a Bloku je obrana národa proti islámu. Analýza však ukázala opak, a byt' je termín národ zmíněn v programu Úsvitu (který je součástí datového korpusu), vyskytuje se $\mathrm{v}$ něm pouze jednou. Podobně jako termíny národ a islám by si zasloužil vlastní analýzu i termín imigrace - předložená analýza Listů se termínu imigrace záměrně vyhýbá, což je i výzvou $\mathrm{k}$ dalšímu výzkumu. Populismus Listů byl potvrzen dle podmínek a výzkumné perspektivy Ernesta Laclaua, protože ho nelze jednoznačně definovat; projevuje se jako hnutí s cílem konstruovat specifickou mentalitu (ve smyslu české identity) a tím společnost rozděluje na dva základní tábory (my vs. oni). Mezi zajímavosti a další dílčí zjištění patří i to, že v Listech není explicitně spojován islám a terorismus. Termíny islám a terorismus jsou spojovány pouze implicitně skrze Islámský stát jako strukturu. Zajímavostí také je, že je v Listech poměrně důsledně odlišována „Evropa“ a Evropská unie. Posledním zajímavým zjištěním je, že některé články mají identický obsah, resp. alespoň část obsahu je identická, nicméně názvy článků jsou odlišné (nejedná se tak pouze o přetisky kvưli regionálním mutacím).

Cílem studie bylo odhalit diskurzivní praktiky reprezentace politické strany Úsvit - národní koalice a zájmové skupiny Blok proti islámu, a to konkrétně ve smyslu tvorby české národní identity jako nástroje pro odůvodnění existence jejich politiky a posílení mentality „českosti“ jako populistické alternativy vůči pro ně pejorativnímu politickému mainstreamu. Kontextuální obsahy, skrze které byl cíl naplněn, jsou zobrazeny $\mathrm{v}$ setech a cíl článku se podařilo naplnit, protože na 
analytických závěrech byly demonstrovány konkrétní diskurzivní praktiky řetězení my vs. oni, které vytváŕí jen populistickou formu pro apelování bez konkrétního politického obsahu (ve smyslu policy). Smysl takového závěru spočívá v apelu na současný výzkum populismu, aby se výrazněji zabýval formálním větvením argumentace aktérů „podezřelých“ z populistické rétoriky. Bez důrazu na diskurzivní praktiky, navíc vztažené k tematizaci demokratické plurality, hrozí nařknutí př́stupů zkoumajících populismus z tematizace „všeho“ a zároveň „ničeho“ (problém holismu), nebo naopak jen něčeho, co navíc nelze nijak (bez definice) uchopit (problém inkrementalismu).

Naplnění cíle prostřednictvím diskurzivních praktik a tematizace demokratické plurality má přidanou hodnotu v možnosti kontextuálního zobrazení, které je blízké sociologické hermeneutice a které zohledňuje i širší kontext politické kultury. Tento rys není u jiných teorií vztahujících se $\mathrm{k}$ populismu tak patrný. Výzkum diskurzivních praktik zohledňující význam demokratické plurality na druhou stranu nenabízí vyčerpávající set vysvětlujících termínů spjatých s výzkumem politických aktérů (politických stran, hnutí a zájmových skupin) a může tak „pokulhávat“ za př́stupy, které jednání a rétoriku populistických aktérů $\mathrm{v}$ zavedených kategoriích vysvětlují (a opírají se v takovém prŕpadě o konceptualizaci extrémní pravice jakožto stranické rodiny).

\section{Literatura a prameny}

Acemoglu, Daron, Georgy Egorov a Konstantin Sonin (2013): „A Political Theory of Populism.“" The Quarterly Journal of Economics: 771-805. DOI: 10.1093/qje/qjs077

Adamec, Miroslav (2016): „Předseda jihočeského BPI k programu do krajských voleb“. Národni listy č. 5, 25. 4. 2016.

Adjei, Stephen B. (2013): „Discourse Analysis: Examinig Language Use in Context.“ The Qualitative Report 18: 1-10.

Arditi, Benjamin (2007): Politics on the Edges of Liberalism. Difference, Populism, Revolution, Agitation. Edinburg: Edinburg University Press.

Bakala, Roman (2016): „Jak Viking vyháněl migranty na plzeňské Viktorce: Ohlas publika, pokuta od svazu“. Národní listy č. 4, 25. 4. 2016.

Beasley-Murray, Jon (2006): „On Populism Reason (Laclau), Populism and the Mirror of Democracy (Panizza), review." Contemporary Political Theory 5: 362-367. DOI: 10.1057/palgrave.cpt.9300255

Betz, Hans-Georg (1994): Radical Right-Wing Populism in Western Europe. Hampshire: Macmillan.

Blok proti islamizaci, z. s. (2016): „Blok proti islamizaci, stanovy.“ On-line (http://blokprotiislamizaci.cz/o-bloku-proti-islamizaci/stanovy/), [ověřeno k 28.7 . 2016].

Blok proti islamizaci, z. s. (2016): „Blok proti islamizaci, stanovy.“ On-line (http://blokprotiislamizaci.cz/o-bloku-proti-islamizaci/stanovy/), ověřeno k 28.7. 2016. 
Borkovcová, Jana (2016a): „Borkovcová: V krajských volbách zastavíme inkluzi...“. Národni listy č. 15, 25. 4. 2016.

Borkovcová, Jana (2016b): „Jana Borkovcová: Ženy, probud’te se!“. Národni listy č. 6, 25. 4. 2016.

Burian, Tibor (2016): „Ing. Burian: Musíme zastavit inkluzi a odmítnout kvóty na imigranty“. Národni listy č. 10, 25. 4. 2016.

Canovan, Margaret (1982): „Two Strategies for the Study of Populism.“ Political Studies 30(4): 544-552. DOI: 10.1111/j.1467-9248.1982.tb00559.x

Císař, Ondřej a Václav Štětka (2016): „Czech Republic: The Rise of Populism From the Fringes to the Mainstream." In: Toril Aalberg, Frank Esser, Carsten Reinemann, Jesper Stromback a Claes De Vreese (eds.), Populist Political Communication in Europe. New York a London: Routledge, 285-298.

Creswell, John W. (2007): Qualitative Inquiry and Research Design. Choosing Among Five Approaches. Thousand Oaks: Sage.

ČRo (2016): „Český rozhlas. Státní zástupce obžaloval Martina Konvičku za výroky proti muslimům na Facebooku.“ On-line (http://www.rozhlas.cz/zpravy/politika/_zprava/ martin-konvicka-je-obzalovan-za-vyroky-proti-muslimum-na-facebooku--1601460), ověřeno k 18. 10. 2016

Dunn, Kris (2015): „Preference for radical right-wing populist parties among exclusivenationalists and authoritarians." Party Politics 3: 367-380. DOI:10.1177/1354068812472587

Fieschi, Catherine (2004): „Introduction.“ Journal of Political Ideologies 9(3): 235-240. DOI: $10.1080 / 1356931042000263492$

Habermas, Jürgen (2000). Strukturálni premèna verejnosti. Praha: Karolinum.

Hanzl, Aleš (2016): „Děti a mladí z pouličních part a od počítačových her na hřiště“. Národni listy č. 7, 25. 4. 2016.

Harper, Alexander S. (2012): „An Oblique Epistemic Defence of Conceptual Analysis“. Metaphilosophy 43(3): 235-256. DOI: 10.1111/j.1467-9973.2012.01742.x

Hatton, Timothy J. (2016): „Immigration, public opinion and the recession in Europe.“ Economic Policy. Migration and public opinion: 205-246. DOI: 10.1093/epolic/eiw004

Hayward, Jack (2004): ,The Populist Challenge to Élitist Democracy in Europe.“ In: Jack Hayward (ed.), Élitism, Populism, and European Politics. Oxford, New York: Clarendon Press Oxford, 10-32.

Hsieh, Hsiu-Fang a Sarah E. Shannon (2005): ,Three Approaches to Qualitative Content Analysis“. Qualitative Health Research 15(9): 1277-1288. DOI: $10.1177 / 1049732305276687$

Idnes.cz (2016): „Blok proti islámu už neexistuje. Vznikla nová Iniciativa Martina Konvičky“. Idnes.cそ, on-line (http://zpravy.idnes.cz/blok-proti-islamu-konvickaalternativa-pro-cesko-fb7-/domaci.aspx?c=A160528_130350_domaci_pku), [ověřeno k 28. 7. 2016].

Klímková, Lenka (2016): „Klímková: Islám je z větší části o krutém boji proti nevěřícím“. Národni listy č. 10, 25. 4. 2016.

Kocourková, Věra (2016): „Kocourková: Žádám postavení islámu mimo zákon“. Národní listy č. 11, 25. 4. 2016.

Koller, Martin (2016): „Stráž obrany státu pro 21. stoletî‘. Národni listy č. 14, 25. 4. 2016. 
Kozdera, Pavel (2016): „Cizinci znásilnili dívku v Pardubicích, ale azyl získat mohou“. Národni listy č. únor, 25. 4. 2016.

Kriesi, Hanspeter a Takis S. Pappas (2015): „Populism in Europe During Crisis: An Introduction." In: Kriesi, Hanspeter a Takis S. Pappas (eds.), European Populism in the Shadow of the Great Recession. Colchester: ECPR Press, 1-22.

Kuras, Benjamin (2016): „Benjamin Kuras: Každá válka začíná nechráněním hranic“. Národni listy č. 9, 25. 4. 2016.

Laclau, Ernesto (1977): Politics and Ideology in Marxist Theory. Capitalism - Fascism - Populism. London: NLB.

Laclau, Ernesto (2005): „Populism: What's in a Name?“ In: Francisco Panizza (ed.), Populism and the Mirror of Democracy. London: Verso, 33-49.

Laclau, Ernesto (2005): On Populist Reason. London: Verso.

Lakoff, George (2004): Don't Think Of An Elephant! White River Junction: Chelsea Green Publishing.

Lakoff, George a Mark Johnson (2002): Metafory, kterými žijeme. Brno: Host.

Linz, Juan J. (2000): Totalitarian and Authoritarian Regimes. London: Rienner.

Maasen, Sabine a Peter Weingart (2000): Metaphors and the Dynamics of Knowledge. London and New York: Routledge.

Mazzoleni, Gianpietro (2008): „Populism and the Media.“ In: Daniele Albertazii a Duncan McDonnell (eds.), Twenty-First Century Populism. The Spectre of Western European Democracy. Hampshire: Palgrave Macmillan, 49-66.

Median (2016a): „Sněmovní volební model. Leden 2016.“ On-line (http:/ /www.median.e u/cs/wp-content/uploads/docs/MEDIAN_Snemovni_volebni_model_2016_01.pdf), ověreno k 18. 10. 2016.

Median (2016b): „Sněmovní volební model. Únor 2016،“ On-line (http://www.median.e $\mathrm{u} / \mathrm{cs} / \mathrm{wp}$-content/uploads/docs/median_snemovni_volebni_model_2016_02.pdf), ověreno k 18. 10. 2016.

Median (2016c): „Sněmovní volební model. Březen 2016.“ On-line (http://www.median. $\mathrm{eu} / \mathrm{cs} / \mathrm{wp}$-content/uploads/docs/median_snemovni_volebni_model_2016_03.pdf), ověreno k 18. 10. 2016.

Median (2016d): „Sněmovní volební model. Duben 2016.“ On-line (http://www.median. $\mathrm{eu} / \mathrm{cs} / \mathrm{wp}$-content/uploads/docs/median_snemovni_volebni_model_2016_04.pdf), ověřeno k 18. 10. 2016.

Median (2016e): „Sněmovní volební model. Květen 2016.“ On-line (http://www.median. $\mathrm{eu} / \mathrm{cs} /$ wp-content/uploads/docs/MEDIAN_Snemovni_volebni_model_2016_05.pdf), ověřeno k 18. 10. 2016.

Mertl, Jiří a Ondřej Hejnal (2013): „Metafory, bezdomovci a média. Metodologický nástin využití analýzy metafor a podpůrného softwaru." Antropowebzin 4: 145-153.

Mudde, Cas a Cristóbal Rovira Kaltwasser (2011): „Voices of the peoples: Populism in Europe and Latin America Compared." Working Paper 378, Kellogg Institute For International Studies.

MVČR (2016a): „Historie strany DOMOV s BLOKEM PROTI ISLAMIZACI.“ On-line (http://aplikace.mvcr.cz/seznam-politickych-stran/Vypis_Historie.aspx?id=209\&typ= 0), ověreno k 28. 7. 2016. 
MVČR (2016b): „Historie strany Úsvit - Národní Koalice.“ On-line (http://aplikace.mvcr.cz/seznam-politickych-stran/Vypis_Historie.aspx?id=392\&typ= 0), ověřeno k 28. 7. 2016.

Novák, Miroslav (1997): Systémy politických stran. Úvod do jejich srovnávacího studia. Praha: Slon.

Odmalm, Pontus a Tim Bale (2015): „Immigration into the mainstream: Conflicting ideological streams, strategic reasoning and party competition." Acta Politica 50(4): 365378. DOI: $10.1057 /$ ap.2014.28

Pasquino, Gianfranco (2008): „Populism and Democracy.“ In: Daniele Albertazii a Duncan McDonnell (eds.), Twenty-First Century Populism. The Spectre of Western European Democracy. Hampshire: Palgrave Macmillan, 15-29.

Pratt, John (2007): Penal Populism. New York: Routledge.

Procházková, Iva (2016): „Š́lené dopady přesunu žáků z praktických škol na základky“. Národni listy č. 7, 25. 4. 2016.

PSPČR (2016): „Poslanecká sněmovna Parlamentu České republiky. Členové Poslanecký klub Úsvit -

Národní Koalice.“ On-line (https://www.psp.cz/sqw/snem.sqw?l=cz\&id=1111), ověřeno k 18. 10. 2016.

Redakce NL (2016a): „Aktuálně o politické kriminalizaci docenta Konvičky“. Národní listy c. 15, 25. 4. 2016.

Redakce NL (2016aa): „Vláda krade se solárními barony. Rozhovor s Martinem Konvičkou a Mirkem Lidinským“. Národni listy č. 4, 25. 4. 2016.

Redakce NL (2016ab): „Zákaz azylu za porušení zákona a referendum za odmítnutí kvót". Národni listy č. 12, 25. 4. 2016.

Redakce NL (2016b): „Brusel je nám na nic, chceme ochranu hranic! Drony a radary na ochranu ČR před migranty“. Národni listy č. 6, 25. 4. 2016.

Redakce NL (2016c): „Co se tutlá?“. Národni listy č. 7, 25. 4. 2016.

Redakce NL (2016d): „Docent Konvička účelově kriminalizován: důkazy obhajoby policii nezajímaji“‘. Národní listy č. 9, 25. 4. 2016.

Redakce NL (2016e): „Emailové úniky usvědčily premiéra Sobotku ze lži o migračních kvótách“. Národni listy č. leden, 25. 4. 2016.

Redakce NL (2016f): „Fond Elišky Přemyslovny ctí ženy a také brání národní identitu“. Národni listy č. únor, 25. 4. 2016.

Redakce NL (2016g): „Hra o oběd v Londýně. Zachraňte Řecko před Islámským státem“. Národni listy č. únor, 25. 4. 2016.

Redakce NL (2016h): „Hrdá a bezpečná země (Program Úsvitu a Bloku proti islámu do krajských voleb)“. Národni listy č. 15, 6, 25. 4. 2016.

Redakce NL (2016i): „Költöová: Rituál Halal na Plzeňsku nechceme“. Národní listy č. 13, 25. 4. 2016.

Redakce NL (2016j): „Konvička je lídrem kandidátky ÚNK a BPI v Jižních Čechách. Rozhovor s Martinem Konvičkou a Mirkem Lidinským“. Národní listy č. 5, 25. 4. 2016.

Redakce NL (2016k): „Konvička má řešení, Sobotka mlži“. Národní listy č. 14, 25. 4. 2016. Redakce NL (20161): „Konvička: Ochrana hranic jako má Británie“. Národní listy č. 14, 25. 4. 2016.

Redakce NL (2016m): „Konvičkův Blok jde s Úsvitem do krajských a senátních voleb. Volby jsou referendem o kvótách a superkvótách“. Národní listy č. 14, 25. 4. 2016. 
Redakce NL (2016n): „Konvičkův Blok proti islámu s Úsvitem do voleb proti imigraci“. Národni listy č. 15, 25. 4. 2016.

Redakce NL (2016o): „Marek Černoch na celoevropské demonstraci Pegidy v Drážd’anech“. Národní listy č. 4, 25. 4. 2016.

Redakce NL (2016p): „Nejsme národem Švejků, jsme národem bojovníkư‘. Národni listy c. 15, 25. 4. 2016.

Redakce NL (2016q): „Proč kuřata v Nýřanech podřezávají podle islámského rituálu“. Národni listy č. 4, 25. 4. 2016.

Redakce NL (2016r): „Prvomájový průvod proti islamizaci (pozvánka)“. Národni listy č. 15, 25. 4. 2016.

Redakce NL (2016s): „Sociolog Hampl: Británie 2050 islámskou zemí. Národní listy č. unor, 25. 4. 2016.

Redakce NL (2016t): „Sociolog Hampl: Zastavme buzeraci českých podnikatelů“. Národní listy c.. 9, 25. 4. 2016.

Redakce NL (2016u): „Stop imigraci. Brusel je nám na nic, chceme ochranu hranic (pozvánka)“. Národní listy č. leden, 25. 4. 2016.

Redakce NL (2016v): „Úsvit a Blok jdou společně do krajských voleb. Rozhovor s Martinem Konvičkou a Mirkem Lidinským“. Národni listy č. 7, č. 10 a ̌̌. 12, 25. 4. 2016.

Redakce NL (2016w): „Úsvit s BPI: Referendum za odmítnutí kvót a za vystoupení z EU“. Národní listy č. 14, 25. 4. 2016.

Redakce NL (2016x): „Úsvit s Konvičkovým Blokem proti islámu do voleb. Rozhovor s Martinem Konvičkou a Mirkem Lidinským. Za zastavení imigrace, inkluze, daňovou konkurenci krajư‘. Národní listy č. 14, 25. 4. 2016.

Redakce NL (2016y): „Úsvit s podporou Bloku kandiduje do krajských a senátních voleb společně. Rozhovor s docentem Konvičkou a válečným veteránem Lidinským“. Národní listy č. leden, 25. 4. 2016.

Redakce NL (2016z): „Úsvit s podporou Bloku spolu do voleb. Proč zrušili facebookové stránky Islám v České republice nechceme“. Národni listy č. únor, 25. 4. 2016.

Redakce NL; Kohout, Pavel (2016): „Pokud dlouhodobě špatně hospodaříme, ztratíme sílu se bránit“. Národni listy č. 15, 25. 4. 2016.

Redakce NL; Konvička, Martin (2016a): „Exkluzivně o Konvičkově obvinění: snaha o dehonestaci pana docenta muslimskou masokostní moučkou“. Národní listy č. 6, 25. 4. 2016.

Redakce NL; Konvička, Martin (2016b): „Je odmítání islámu rasistické?“. Národní listy č. 5, 25. 4. 2016.

Ricoeur, Paul (2000): Cas a vyprávèní. Praha: Oikoymenh.

Sartori, Giovanni. (2005): Strany a stranické systémy. Schéma pro analýzu. Brno: Centrum pro studium demokracie a kultury.

Stavrakakis, Yannis (2004): „Antinomies of formalism: Laclau's theory of populism and the lessons from religios in Greece." Journal of Political Ideologies 9(3): 253-267. DOI: $10.1080 / 1356931042000263519$

Stockemer, Daniel (2016): „Structural Data on Immigration or Immigration Perceptions? What Accounts for the Electoral Success of the Radical Right in Europe?" JCMS: Journal of Common Market Studies 54 (4): 999-1016. DOI: 10.1111/jcms.12341

Strauss, Leo (1995): Eseje o politické filosofii. Praha: Oikoymenh. 
Svoboda, Martin (2016): „STOP imigraci, zelená národní hokejové hrdosti“. Národní listy c. 6, 25. 4. 2016.

Toepfer, Thomas (2016): „Vlastenectví - přežitek nebo budoucnost?“. Národni listy $\check{c} .6$, 25. 4. 2016.

Tyneside (2016): „Tyneside s.r.o.“. On-line (http://www.tyneside.cz/), [ověřeno k 28. 7. 2016].

Úsvit (2016): „Úsvit - Národní koalice.“ On-line (http://www.usvitnarodnikoalice.cz/), [ověřeno k 28. 7. 2016].

Voegelin, Eric (2000): Nová véda o politice. Brno: Centrum pro studium demokracie a kultury.

Wodak, Ruth (2015): The Politics of Fear: What Right-Wing Populist Discourses Mean. London and New York: Sage.

Ziai, Aram (2004): „The ambivalence of post-development: betweem reactionary populism and radical democracy." Third World Quarterly 25(6): 1045-1060. DOI: $10.1080 / 0143659042000256887$

\section{A Discursive Analysis of Národní listy: Nation vs. Islam and the Laclau Matrix}

\section{SUMMARY}

The aim of this study is to establish a context for understanding the term "nation" in terms of the discursive community of political actors that belong to the coalition DawnNational Coalition political party (Úsvit - národni koalice) and the Block. Against Islam (Blok proti islámu) interest group as well as the term's hypothetical semantic opposite, which can be expressed by the term "Islam". Establishing a context for understanding this term can help us to more fully comprehend the mechanism of creating populist mentalities through the formulation of an "other" and, by doing so, co-creating a discursive idea of the Czech nation as an integral part of the political program of the actors mentioned above. For this reason, the "National Papers" (Národní listy) periodical will be analysed, as it is the official paper of the party of coalition actors mentioned above and represents their own program priorities.

Laclau's discursive understanding of the expressions of populism serves as the theoretical basis for this study. Laclau characterizes populism through the absence of specific content in populist statements, in which populists place emphasis on the method of argumentation (and not on content). The populist method of argumentation is characterized by an asymmetry that defies the logic of pluralistic differences and bases its concept on the social frustration of the defined group (the nation) and its differentness from another group. The method of populist argumentation is chain-like - if frustration stems from one dissatisfied state, it then links to another, and another, etc. In this manner, the problem leads to a chain reaction until it is generalized into the complete and 
unsatisfactory social standing of the individual in question (on the part of the nation). Thus, this frustration is strengthened and the stronger the frustration is, the larger the need to deal with this frustration and to designate an offender. A competing causal chain of "facts" is created, which is the cause of frustration, as in it lies the causes of the given political frustration. In this manner, chains of stereotypes are created - one signifies the frustrated state and the other signifies its causes. The purpose of this is to acquire hegemony in the interpretation of the political reality and thus transform the political mentality. If we look at this state from a critical perspective, democratic plurality disappears with the presence of a hegemony, posing a danger to democratic societies.

A specific goal of this study is to reveal the discursive practices used by the representation of the Dawn - National Coalition political party and the Block. Against Islam. Both actors create Czech national identity as a tool for justifying the existence of their policy and strengthen the mentality of "Czechness" as a populist alternative against the political mainstream (which is, to them, negative). This study aims to contribute to the discussion on the research of the basic concepts linked to the emergence of new single issue political parties and also possibly to the discussion on political parties' expansion of program points to include national and anti-Islamic issues. Analysed discourse practices include concepts on "Islamic immigration" and the protection of traditional (i.e. European and Czech) values, which attempt via their content to create a populist mentality. Value-heavy stereotyping of the terms "nation" and "Islam" is thus a prerequisite which can lead to the creation of a populist mentality and the disqualification of a group of individuals from public space who do not fall ideologically into the stereotype of "nation" (via the negative signification of "Islam"). If such a state arises, democratic discussion becomes limited, for example in the form of practical articulation of stereotypes.

The results of the analysis of discursive practices can be summarized in several points. Firstly, Islam is a more serious topic for the National Papers periodical than the topic of nation is: in terms of its frequency, it appears more than four times as often; it is understood as an acute threat to the nation; and, finally, Islam is linked to migration and migration to illegality. Secondly, the Czech nation is linked to its history, which is different from Islam - the Czech nation is humane and cultural, but also proud, brave, and combatant. Thirdly, Czech identity is threatened by the competing identity of the European Union, which is pseudo-humane and acultural. Generally speaking, a specific mentality of an evil surrounding the Czech nation is created. This evil does not represent our interests and stands in contradiction to them; the term "nation", however, is empty, as its content is undetermined - only its form is emphasized. Fourthly, Islam is understood as a life philosophy and culture that endangers the Czech nation and is manifested in rituals that are frightening, inhumane, unhygienic, and primarily serve to generate money for the support of the Islamic community. The spread of this culture is linked to immigration, immigration is linked to the Islamic State, and the Islamic State is linked to terrorism. The nation must defend itself against such a process and must support Czech pride and active defence using democratic means.

This interpretation provides the following results: Dawn and the Block Against Islam take a populist stance in the National Papers. They stylize Islam as a threat to Czech identity and as one that is gradually strengthening. In doing so, they evoke a fear of endangerment. Then they cultivate this fear and take the role of those who represent the 
members of the brave and intrepid Czech nation, all while failing to mention what this nation is and who should actually belong to it (i.e. what the criteria for Czechness are and whether it is enough to dislike the establishment, the European Union, and Islam). The criteria are unclear, as establishing them is not actually the point of populism; what is important is the form in which such a mentality is created. Similarly, the criteria for Islam are also unclear, with the exception of the ritual of halal and the Koran being used as a source of ideology. The National Papers do not define the content of Islam or what exactly the Czech nation should be afraid of, with the exception of the violation of women's human rights, which are also not specified (what rights are entailed here exactly?). As terms and components of discursive structure, the words "Islam" and "the Czech nation" lack clear content. Relations between the two are negative. As the analysis of the National Papers reveals, populism is expressed by creating two worlds - our Czech world and the other world (the world of the identity of the European Union and the world of Islam). In doing so, one of the main conditions of populism is fulfilled. The Czech establishment stands between these worlds and distances itself from Czech identity by defending "their" interests and not "ours". Dawn and the Block Against Islam are attempting to assume the role of the new elite that will stand by our side, creating a specific populist mentality that is actually based on unclear terms and the promise of greater power for citizens in the form of a referendum on immigration.

The populism of the National Papers was confirmed according to the conditions and research perspective of Ernesto Laclau, as it impossible to define this populism clearly; it manifests itself as a movement aiming to construct a specific mentality (in the sense of a Czech identity) and, by doing so, divides society into two basic camps (us vs. them). Other interesting findings include the fact that Islam and terrorism are not explicitly linked to one another in the National Papers. The terms Islam and terrorism are connected only implicitly via the Islamic State as a structure. It is also interesting to note that the National Papers also quite consistently differentiate "Europe" from the European Union.

The goal of this study was fulfilled via research into the discursive practices and thematization of democratic plurality. Its added value lies in the portrayal of a context that is closely connected to sociological hermeneutics and takes into consideration the wider context of political culture. This characteristic is not as evident in other theories relating to populism. On the other hand, the research of discursive practices dealing with the significance of democratic plurality does not offer an exhaustive list of explanatory terms linked to the research of political actors (political parties, movements, and interest groups), and therefore may be "weaker" than other approaches that explain (in this context, based on the notion of the extreme right) the behaviour and rhetoric of populist actors in these given categories. 